IJTI (International Journal Of Transportation And Infrastruct ure)

Available Online @ http://jumal.na rotama.ac.id/index.php/ijti ISSN : 2597-4769 (ONUNE) ISSN : 2597-4734 (CETAK)

\title{
POLAR STORAGE METHOD AS ONE QUALITY CONTROL OF RAW MATERIAL FEEDBACK
}

\author{
Prama Wildan Ardiansyah \\ Narotama University, Surabaya, Indonesia \\ e-mail: wildanardiansyah@gmail.com
}

\begin{abstract}
In today's economic development where the business world is growing rapidly, the employers are required to work more efficiently to deal with the tightness of business competition in Indonesia. The continuity of the production process within a company will be influenced by various factors including: Capital, Technology, raw material inventory, finished goods inventory and labor. In addition, the production process must be supported by a good raw material storage process as well.
\end{abstract}

Keyword : Polar storage, raw material, method

\section{INTRODUCTION}

An industry especially large scale industry, warehousing component or raw material storage is a very important aspect to be considered. Large scale feed industry performs the process of receiving raw materials in large quantities and the storage time in quite long. If the raw material is large, and not disposable, but its use gradually, then the stability of the goods must be maintained to maintain the quality. This of course requires an effective warehousing and storage system for raw materials and finished products manufactured(Badruddin, 2009; Halim \& Sriwahyuni, 2017).

In the storage process, any materials and finished products will have a chance of damage. The damage can be physical damage or chemical and biological damage. Physical damage to storage may be a trigger for chemical and biological damage. Therefore, the physical properties of a material is very important to know in advance before the storage of materials. Physical properties of the material include moisture content, specific gravity, water activity, pile angle, material fineness, collision density, material compaction density, and so forth.

\section{METHOD}

The object of this paper is the storage of animal feed. Where to choose the best storage method in terms of storage of feed raw materials. Each method has its own advantages and disadvantages. Through the analysis of the data will be selected the best method. 


\section{DISCUSSION}

Storage Definition

According to Subagya (2012) storage can be defined as an activity and effort to make arrangements, organizing and arrangement of inventory goods in the storage room.

Storage is a storage activities logistics processes and equipment in the warehouse by placing logistics and equipment received:

1. Placement according to floor plan.

2. Safe from theft.

3. Safe from physical breakdown.

4. Safe from the chemical and biological pollution that can damage the quality and quantity.

5. Safe from fire.

6. Arrangement in accordance with warehousing standards.

\section{Warehousing Definition}

Warehousing is the activity of storing goods in warehouses. While according to Sukadarto (2010), Warehousing is the activities of shelter, storage, security and distribution of goods that become the need for every organization.

\section{Understanding the Warehouse}

According to Lucas and Rumsari (2014) Warehousing is a series of activities in the storage of logistics from the activities of reception, recording, entry, storage, arrangement, bookkeeping, maintenance, expenditure and distribution up to accountability activities of warehouse management (making reports) in order to support the continuity of work unit work, while supporting the effectiveness and efficiency of the organization as a whole.

From the above understanding can be said that warehouse not only store goods in the warehouse. But it covers many activities such as recording, maintenance, arrangement, bookkeeping and other activities(Sari, Madonna, Nursetyowati, \& Wajdi, 2018; Setiawan, Sukoco, Purworusmiardi, Wajdi, \& Kurniasih, 2017).

\section{Storage Procedure}

Storage of feed raw materials can be done in various ways. These storage methods are adapted to the type and specification of feed ingredients to facilitate the process of storing and unloading stored materials. Some of these storage methods include storage in warehouses with packaging, storage in bulk warehouses on warehouse floors, bulk storage in tanks and bulk storage in silos, and other storage methods. 
IJTI (International Journal Of Transportation And Infrastruct ure)

Available Online @ http://jumal.na rota ma.ac.id/index.php/ijti ISSN : 2597-4769 (ONUNE) ISSN : 2597-4734 (CETAK)

\section{Storage in the form of packaging inside the warehouse}

Feed ingredients are stored in the warehouse in the form of packaging. Before being stored in the warehouse, feed ingredients must first be packed in sacks. The type of sack used can be either plastic or jute sack, or a combination between the two. For certain feed ingredients there are even packed in bags made of paper(Enda \& Brata, 2018).

\section{Storage in the Form of Bulk in the Warehouse}

Storage in the form of bulk in the warehouse means that the ingredients of food spilled on the floor of the warehouse that has been given bulkhead or no partition.

\section{Storage in the Form of Bulk in Silo}

Storage in bulk form in silos means that the feed material is stored in bulk form on the floor in a special cylindrical storage space called the silo. The floor of the warehouse (silo floor) forms a cone with a pointed position at the bottom, so the feed material will accumulate downward. The storage and disassembly process requires the help of a transport system (conveyor) that runs automatically by using electricity. Storage of this method is usually done for seed ingredients in the form of grains, such as yellow corn.

\section{Storage in bulk form in tangka}

This way storage is used for liquid feed ingredients. Such as molasses or vegetable oils. The storage bu this way is usually equipped with a pump to facilitate the process of removal of materials to be used in the manufacture of feed.

\section{Storage in another form}

Feed ingredients are not always in the form of sack packaging, either sacks of jute, plastic bags, or bags (zak) made of paper, or in bulk form. There are sometimes when the feed material is packed with cardboard, cans or drums. These ingredients usually consist of medicines, vitamins and amino acids. For these materials storage systems are the same as storage in the warehouse, but require special requirements and treatment in accordance with the characteristics of the material, for example, must be in an air-conditioned room.

Here is a comparison of advantages and disadvantages between storage systems in sacks and bulk storage.

\begin{tabular}{|c|l|l|l|}
\hline No & \multicolumn{1}{|c|}{ Factor } & \multicolumn{1}{c|}{ Sack System } & \multicolumn{1}{c|}{ Bulk System } \\
\hline 1 & Flexibility & Flexible & not flexible \\
\hline 2 & Possible mechanization & less full & full \\
\hline 3 & handling & Slow & Fast \\
\hline
\end{tabular}




\begin{tabular}{|c|c|c|c|}
\hline & $\begin{array}{r}\text { IJTI (International } \\
\text { Available Online } \\
\text { ISSN : 2597- }\end{array}$ & $\begin{array}{l}\text { ansportation And Infrastruct } \\
\text { al.na rota ma.ac.id/index.php// } \\
\text { : ISSN : 2597-4734 (CETAK) }\end{array}$ & \\
\hline 4 & Spill & Many missing & few lost \\
\hline 5 & Capital & Small & Big \\
\hline 6 & Operating cost & High & Low \\
\hline 7 & Danger of rat attack & Big & Small \\
\hline 8 & Pest attack & $\begin{array}{l}\text { Over and over } \\
\text { again }\end{array}$ & Seldom repeats \\
\hline
\end{tabular}

\section{Conclusion}

\section{CONCLUSION}

From the results that have been listed in the table we can conclude that each storage method has advantages and disadvantages of each. In this case the authors conclude that the method of a good or effective storage system for feed raw materials is the method of bulk storage system. In addition to fast handling, the risk of materials lost and the danger of attack of rats and pests is smaller when compared with storage methods using sacks. It's just that for the bulk storage method requires a larger capital for the construction of warehouses, silos and tanks.

\section{Suggestion}

Based on the conclusions of the study, the authors recommend the form of suggestions as follows:

1. Build the type of warehouse in accordance with the raw material to be stored. Build a silo if the raw material is grain-shaped like yellow corn. Build a tank if the raw material to be used is liquid.

2. The authors hope this paper can help the community and students in solving the problem of warehousing.

\section{REFERENCES}

Artaya, I Putu., 2018, Dasar-Dasar Manajemen Operasi dan Produksi, Narotama University Press, Surabaya.

Artaya, I Putu., Arimbawa, I Gede, 2008, Penerapan Metode Korelasi dalam Mengukur Hubungan Antara Customer Relationship dengan Customer Loyalty Pada PT. Antika Raya Surabaya, Jurnal Bisnis dan Manajemen Universitas Negeri Surabaya. Vol. 1, No. 1.

Artaya, I Putu.,Kamisutara, Made., Baktiono, R Agus., 2018, Pengaruh Citra Produk Berdasarkan Analisis Persepsi Konsumen Pada Kelompok Usaha Aneka Pangan Di Sidoarjo, E-Jurnal Tata Sejuta STIA Mataram, Vol. 4, No. 1.

Direktorat Pembinaan SMK. Agribisnis Pakan Ternak Unggas Untuk Kelas 11 Semester 3. Jakarta : Kementerian Pendidikan dan Kebudayaan RI, 2013

Dwiantara, Lukas., Sumarto, Rumsari. 2005. Manajemen logistik. Jakarta: Grasindo 
JFX. Susanto S., Baktiono, R Agus, Artaya, I Putu., 2018, Optimization of governance model of post-food harest and distribution in msme centers in 5 subdistricts in sidoarjo regency, Journal of Economics, Business \&amp; Accountancy Ventura, Vol. 20, No. 3.

Subagya, M S. 2012. Manajemen Logistik. cetakan keempat Jakarta : PT Gunung Agung

Sukadarto. 2010, Model Penyimpanan Bahan Baku Padat. Andi, Yogyakarta.

Badruddin, S. (2009). Miskin dan kesenjangan sosial di Indonesia pra dan pasca runtuhnya orde baru.

Enda, S. K., \& Brata, D. P. N. (2018). DAMPAK PENERAPAN MODEL PEMBELAJARAN KOOPERATIF TEAM GAME TOURNAMENT (TGT) BERBASIS KARAKTER GURU PPKN DI SMKN 1 MOJOAGUNG. JOURNAL PROCEEDING, 4(1).

Halim, P., \& Sriwahyuni, I. (2017). Patient Satisfaction Level at Local General Hospital in Mamuju Regency, Indonesia. International Journal of Science and Research (IJSR), 6(9), 1-5. Retrieved from https://pdfs.semanticscholar.org/ae7c/429df677e8c56cc18eccc5328f6692da62c $0 . p d f$

Sari, D. A. P., Madonna, S., Nursetyowati, P., \& Wajdi, M. B. N. (2018). PUBLIC RECEPTION ON THE USE OF RECYCLED ABLUTION WATER. Jurnal Darussalam: Jurnal Pendidikan, Komunikasi Dan Pemikiran Hukum Islam, 9(2), 222-231.

Setiawan, M. I., Sukoco, A., Purworusmiardi, T., Wajdi, M. B. N., \& Kurniasih, N. (2017). Pengembangan Bandara Udara, dampaknya dalam Peningkatan Wisata Halal dan Wisata Muslim di Indonesia. AT-Tahdzib: Jurnal Studi Islam Dan Muamalah, 5(2), 125-147. 